УДК 330.12

DOI: https://doi.org/10.32840/1814-1161/2019-6-14

Lytvynenko Alina

$\mathrm{PhD}$ in Economics

Associate Professor of the Department of Enterprise Economics and Management Simon Kuznets Kharkiv National University of Economics

ORCID: 0000-0003-0372-5130

Литвиненко А.О.

кандидат економічних наук, доцент, доцент кафредри економіки підприємств і менеджменту Харківського національного економічного університету імені Семена Кузнеця

\title{
DEVELOPING THE MECHANISM OF INFLUENCE OF HR POLICY INSTRUMENTS ON THE EFFICIENCY OF ENTREPRENEURIAL ACTIVITY
}

\author{
ФОРМУВАННЯ МЕХАНІЗМУ ВПЛИВУ \\ IHСТРУМЕНТІВ HR ПОЛІТИКИ НА ЕФЕКТИВНІСТЬ \\ ПІДПРИєМНИЦьКОї дІЯЛЬНОСТІ
}

The concept of developing the managerial mechanism to develop an effective strategy of organization's HR policy development is introduced. In this case, the author's hypothesis comes down to the necessity to subordinate the parameters of the organization criteria for effective HR policy to the interests of the main stakeholders of the integrated business structure related to the perception of the influence of threat factors and developing a reaction to such an impact. The concept of information support to ensure effective business performance is introduced. The system of hypotheses and theoretical principals to improve the effective application of HR policy instruments to manage economic and production systems is determined. The organization process is disclosed using the methodology of structural analysis and modelling. Evaluating the effectiveness of the HR company policy is examined from the point of view of its orientation towards ensuring the functioning of the management mechanism in the modern management system. The results of the analysis to implement the effective HR measures allow us to determine whether the selected personnel strategy is appropriate, favourable and productive. The basis of such evaluation is the analysis of the comparison of costs and results connected with department performance as well as the analysis of their impact on the results of the company in dynamics.

Keywords: HR analytics, HR metrics, human resources, effective management, evaluation of the effectiveness.

Подано концепцію фрормування механізму управління щодо розробки ефективної стратегії розвитку кадрової політики організації. Авторська гіпотеза при цьому зводиться до необхідності підпорядкування параметрів організації критеріїв ефективності HR політики інтересам основних стейкхолдерів інтегрованої структури бізнесу, пов'язаним зі сприйняттям впливу чинників-загроз та з формуванням реакції на такий вплив. Представлена концепція інформаційного забезпечення ефективності підприємницької діяльності організації. Визначено систему гіпотез та теоретичних положень щодо підвищення ефективності застосування інструментів HR політики для менеджменту економіко-виробничих систем. Процес організації розкрито з використанням методології структурного аналізу та моделювання. Оскільки ідентифрікація підприємницьких інтересів відбувається на основі формування архітектурної моделі інтегрованого утворення, то й процес розробки ефективної стратегії розвитку кадрової політики організації подано у вигляді відповідних інструментів, визначених у межах цієї моделі. Сформовано теоретико-методологічний базис організації ефективного забезпечення управління економічною безпекою та розроблено інструментарій планування основних техніко-економічних показників діяльності підприємства з урахуванням запропонованих заходів. Поставлено та вирішено наступні завдання: ідентифріковано підхід до інтеграції процесу з контурами управління ефективністю підприємницької діяльності та сорормовано рекомендації щодо підвищення ефективності застосування інструментів HR політики. Реалізація зазначених завдань базувалась на застосуванні ресурсної парадигми стратегічного менеджменту. Водночас ідентифріковано особливості застосування окремих елементів архітектурної моделі щодо опису життєдіяльності інтегрованої структури HR політики та підтримки ї̈ безпеки. Організація оцінки ефективності HR політики розглянута як із погляду їі орієнтації на забезпечення роботи механізму управління в системі сучасного менеджменту. Результати аналізу ефективності проведених кадрових заходів дозволяють визначити, 
чи є обрана кадрова стратегія доцільною, сприятливою і плідною. В основу такої оцінки покладено порівняння витрат і результатів, пов'язаних з діяльністю кадрових служб, а також аналіз їх впливу на підсумки діяльності підприємства в динаміці. Результати оцінки є індикаторами проблем роботи з персоналом $і$ якістю виконуваної роботи, задоволеності працівників, плинності кадрів та ін.

Ключові слова: HR аналітика, HR метрики, кадровий потенціал, ефрективне управління, оцінка ефрективності.

Представлена концепция фрормирования механизма управления по разработке эфорективной стратегии развития кадровой политики организации. Авторская гипотеза при этом сводится к необходимости подчинения параметров организации критериев эфрфективности HR политики интересам основных стейкхолдеров интегрированной структуры бизнеса, связанным с восприятием влияния фракторов-угроз и с формированием реакции на такое воздействие. Представлена концепция информационного обеспечения эфффективности предпринимательской деятельности организации. Определена система гипотез и теоретических положений по повышению эфрфективности применения инструментов HR политики для менеджмента экономико-производственных систем. Процесс организации раскрыт с использованием методологии структурного анализа и моделирования. Организация оценки эфрфективности HR политики рассмотрена с точки зрения ее ориентации на обеспечение работы механизма управления в системе современного менеджмента. Результаты анализа эфффективности проведенных кадровых мероприятий позволяют определить, является ли выбранная кадровая стратегия целесообразной, благоприятной и плодотворной. В основу такой оценки положен анализ сравнения затрат и результатов, связанных с деятельностью кадровых служб, а также анализ их влияния на итоги деятельности предприятия в динамике.

Ключевые слова: HR аналитика, HR метрики, кадровый потенциал, эфрфективное управление, оценка эфрфективности.

Problem statement. In modern conditions the effective enterprise performance depends directly on the efficiency and quality of its personnel. The company efficiency depends on the employees' qualification, their placement and usage; this affects the volume and rate of production growth, material and technical means usage. One or another way of using the personnel is directly related to the change in the productivity index. The growth of this indicator is the most important condition to develop the company and the main source of national income growth. Personnel management goals and objectives are implemented through personnel policy.

Developing the HR company policy begins with identifying the potential opportunities in the field of personnel management and identifying the areas of work with personnel that should be strengthened for successful implementation of the organizational strategy. Moreover, the HR policy must increase the company capabilities and effectively respond to changes in the market environment.

Overview of recent research and studies. The relevance of the concept of $\mathrm{HR}$ analytics research is explained by the necessity of its applying in strategic planning, because searching new forms and methods of organization and HR management is a key issue to improve competitiveness.

The issue of the influence of HR policy on the effectiveness of business activity was considered by domestic and foreign authors: Vonberg T.V., Denisenko M.P., Budyakova O.Yu., Sivalneva M.M., Shvekov A.V., Nikiforenko V.G., Kasich A.O., J. Atkinson, D. McClelland and others.

HR analytics is a process where data processing techniques and business analytics are applied to HR data processing. It is also sometimes called talent analytics. There are two main goals in the HR analytics: providing insights (previously unknown information) and identifying key data [1].

The first goal is to provide the company with information about its own operations that can help to manage employees effectively and, as a consequence, achieve company's business goals.

The second key function of the HR analytics is to provide models to predict the various ways by which company can get the best return on its human capital investment.

In general, the HR analytics is focused on maximum usage of vast amounts of human resources data which are collected by the most companies.

Highlighting previously unresolved parts of a common problem. In modern conditions business requires HR services not only to perform their tasks effectively but also to rise to the level of a business partner who is able to make a significant contribution to achieve the strategic company goals [2].

The verification of this trend can be the appearance in leading Ukrainian companies a position of HR business partner. Its main tasks are to improve company business performance indicators and to promote the long-term company development by improving the efficiency and productivity of the staff as well as improving the process of personnel management [3].

Nowadays, a large number of key indicators of the effectiveness are used to analyze the effectiveness of the HR policy. They can be conditionally divided into several groups: productivity, working conditions, professional behaviour, and personal qualities. In practice, key indicators of the effectiveness of the company HR policies are presented in several categories (Figure 1).

Key indicators of the effectiveness as management instruments allow to: clearly formulate and quantify goals; monitor the results; timely diagnose complex situations requiring managerial intervention; timely adjust goals by optimizing plans; delegate authority; evaluate the level of management, the effectiveness of the departments and develop the most successful business directions; motivate employees to achieve results; objectively evaluate the employees' effectiveness.

The implementation of the management system with key indicators of the effectiveness allows keeping control on key parameters in a given corridor, building an 


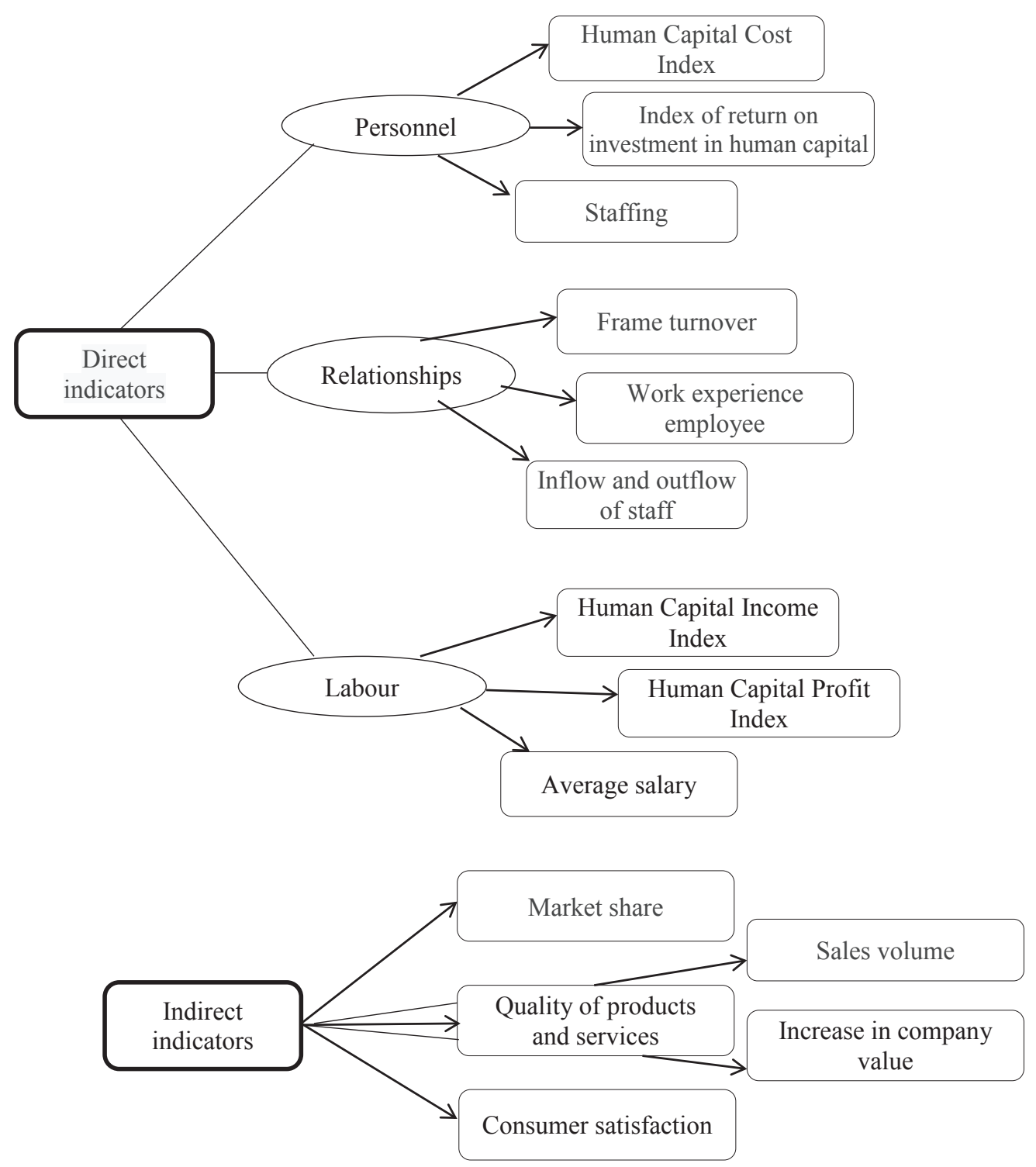

Figure 1. Key indicators of the effectiveness of company HR policy

(summarized by the author $[5 ; 6 ; 7]$ )

effective system of employee motivation, and finding timely critical points and bottlenecks in the departments' performance or company as a whole. For every company, the set of key indicators of the effectiveness can be completely different, as the global company goals and objectives are also different.

According to the analysis of the above criteria, the priority directions to improve the effectiveness of HR policy can be identified (Table 1).

Purpose statement. The purpose of the article is to distinguish key indicators of the efficiency of the company HR policy into different categories; to review the instruments of the company HR policy and to analyse their impact on the efficiency of company performance; to summarize the impact of HR policy on the efficiency of company.

Statement of the main research material. The most clearly correlated development of the company and HR policy is revealed in the classification of strategies, taking into account the situational factors. According to this approach, there are several situational strategies related to certain stages of company development (Table 2 summarized by the author on the basis of $[8 ; 9 ; 10 ; 11])$.

Based on the analysis of the dependence of the HR policy on the type of company strategy, we can conclude that it is a general direction of work with staff, which ensures the combination of the company goals with the employees' goals and provides procedures for staff standardization, programming and monitoring.

HR decisions are often based on professional instincts and intuition. HR analytics can help to improve productivity and predict the most successful models. This eliminates most of the human error in decision making and allows converting HR to accurate science with the right instruments.

A common mistake when implementing metrics is to include too many of them in the system. The key question when choosing individual metrics may be the wording: "What strategic business decision can this metric be useful for?" The key requirements for choosing metrics are listed in Diagram 2. 
Priorities to improve effectiveness of HR policy

\begin{tabular}{|c|l|}
\hline \multicolumn{1}{|c|}{ Indicator } & Organizational and economic instruments \\
\hline \multicolumn{1}{|c|}{$\mathbf{1}$} & \multicolumn{1}{c|}{$\mathbf{2}$} \\
\hline The level of complexity of work & $\begin{array}{l}\text { Coaching and mentoring } \\
\text { Goal setting } \\
\text { Competence management } \\
\text { Talent management } \\
\text { E-learning } \\
\text { Delegation of authority } \\
\text { Function distribution }\end{array}$ \\
\hline \multirow{3}{*}{ The level of quality of work } & $\begin{array}{l}\text { Payment } \\
\text { Staff evaluation, training and development. } \\
\text { Social justice }\end{array}$ \\
\hline \multirow{3}{*}{ The level of labour intensity } & $\begin{array}{l}\text { Time management } \\
\text { Adjustment of uniformity of work load } \\
\text { Adequate level of labour protection }\end{array}$ \\
\hline \multirow{3}{*}{ The level of labour tensions } & $\begin{array}{l}\text { Organizing teamwork } \\
\text { Managing employee engagement } \\
\text { Information Technology } \\
\text { Corporate culture } \\
\text { Adjusting the workload uniformity }\end{array}$ \\
\hline
\end{tabular}

Table 2

Dependence of HR policy on the type of company strategy

\begin{tabular}{|c|c|c|c|}
\hline № & Type of strategy & Characteristic & Features of HR policy \\
\hline 1 & 2 & 3 & 4 \\
\hline 1 & Entrepreneurial & $\begin{array}{l}\text { It is typical for companies } \\
\text { engaged in a new activity } \\
\text { that focuses on meeting } \\
\text { all the requirements of the } \\
\text { customer. }\end{array}$ & $\begin{array}{l}\text { Features of HR Policy: } \\
\text { 1. Selecting employees who are focused on long-term work. } \\
\text { 2. Competitive reward that meets the expectations of the employee. } \\
\text { 3. Planning of HR movements taking into account the interests of } \\
\text { employees. }\end{array}$ \\
\hline 2 & $\begin{array}{l}\text { Dynamic } \\
\text { development } \\
\text { strategy }\end{array}$ & $\begin{array}{l}\text { The degree of risk is much } \\
\text { lower, the foundation for } \\
\text { the future of the company is } \\
\text { laid, all decisions are made } \\
\text { on the basis of comparison } \\
\text { of goals and means needed } \\
\text { for their achievement. }\end{array}$ & $\begin{array}{l}\text { Features of HR management strategy: } \\
\text { 1. Selecting and positioning the staff are aimed at finding flexible } \\
\text { and loyal employees who are willing to take risks. } \\
\text { 2. A fair reward for the achieved goals; } \\
\text { 3. Evaluation of the performed work according to clearly defined } \\
\text { criteria. } \\
\text { 4. Planning movements taking into account the real company } \\
\text { opportunities and various forms of official promotion. }\end{array}$ \\
\hline 3 & $\begin{array}{c}\text { Profitability } \\
\text { strategy }\end{array}$ & $\begin{array}{l}\text { The focus is on maintaining } \\
\text { the existing level of the } \\
\text { company profit. The same } \\
\text { is subordinated to the HR } \\
\text { strategy }\end{array}$ & $\begin{array}{l}\text { Features of HR profitability strategy: } \\
\text { 1. Selecting and positioning the staff are maximum rigid. } \\
\text { 2. A narrow, result-oriented activity evaluation. } \\
\text { 3. The scheduling of movements is rigid, according to the } \\
\text { management's perceptions of expediency. }\end{array}$ \\
\hline 4 & $\begin{array}{c}\text { Elimination } \\
\text { strategy }\end{array}$ & $\begin{array}{l}\text { The purpose is to sell } \\
\text { company assets to eliminate } \\
\text { losses. In future, staff } \\
\text { reductions are possible, as } \\
\text { a further drop in profits is } \\
\text { expected. }\end{array}$ & $\begin{array}{l}\text { The HR management strategy is as follows: } \\
\text { 1. Recruitment is unlikely. } \\
\text { 2. Merit-based payment is virtually non-existent, with no additional } \\
\text { incentive. } \\
\text { 3. Development and training are only in case of business necessity; } \\
\text { promotion is only for those who have the necessary skills. }\end{array}$ \\
\hline 5 & $\begin{array}{c}\text { Circulation } \\
\text { strategy }\end{array}$ & $\begin{array}{l}\text { The main goal is to save the } \\
\text { company. In order to survive } \\
\text { the redundancies are often } \\
\text { taken. }\end{array}$ & $\begin{array}{l}\text { The HR management has the following characteristics: } \\
\text { 1. Selection of versatile staff. } \\
\text { 2. Payment by incentive system and merit review. } \\
\text { 3. Careful selection of applicants for advanced training }\end{array}$ \\
\hline
\end{tabular}

One of the useful instruments for the HR function on the way to business partnership is HR metrics: they are indicators that allow evaluating or measuring HR processes in a company as well as compare the resulting indicators with selected benchmarks (e.g. with similar indicators of successful companies in the market, not necessarily in one industry).

Therefore, developing and implementing an effective HR metric system requires deep understanding of the company's business, its strategy and core business goals from the HR managers. Experience in conducting HR metrics systems development and implementation projects for leading companies in the Ukrainian market demonstrates the importance of engaging company executives from the earliest stages of developing and implementing HR metrics systems to ensure a close relationship with the company's business and strategy. 


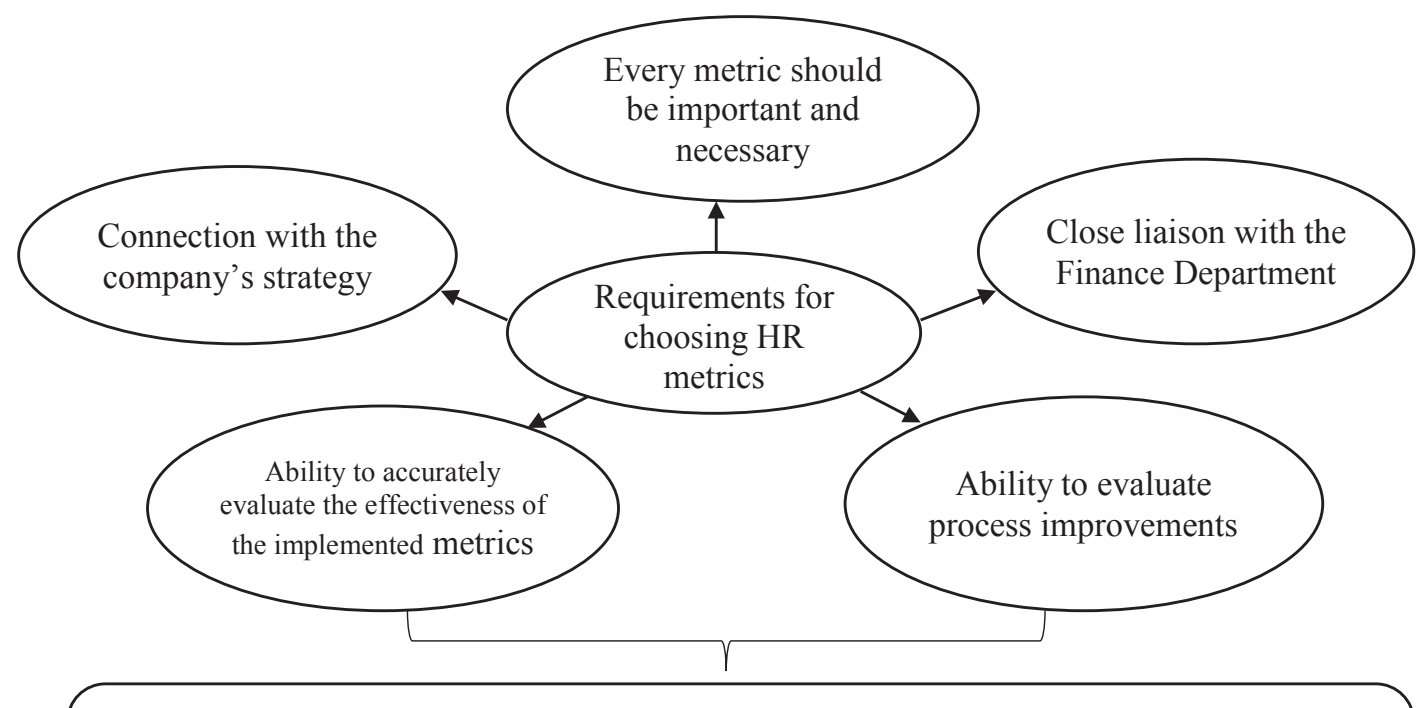

When implementing the HR metrics system, HR managers should answer the key questions:

What is the most important for the company today / in the next 3-5 years?

What can HR management function do to help a company achieve its business goals?

Diagram 2. Key requirements to select HR metrics

(highlighted by the author on the basis of $[1 ; 4]$

HR analytics is an integral part of data management, and its implementation can deliver a positive return for any company. Statistics on foreign companies states that the effect of implementing the HR evaluation system covers the costs of its implementation and has a positive impact on strategic decisions. But as it is shown above, managing, analyzing, and interpreting data are not simple processes. The key to successful HR analytics is based on the understanding that it is not the size of the measured data gives results but rather the impact of the data on decision making in the company.

Conclusions. Thus, the personnel policy is aimed at creating such a system of work with HR, which would be oriented to obtain not only economic but also social effect, subject to compliance with current legislation, regulations and governmental decisions. In order to evaluate the effectiveness of the HR strategy of the company and its implementation, it is necessary to understand the conditions of functioning of the company HR service and its interaction with all stakeholders.

Thus, the improvement of the HR policy implies the introduction of qualitatively new methods of the HR management and a high level of professionalism and interaction with the company management.

\section{Бібліографічний список:}

1. Вонберг T. В. HR аналітика як підґрунтя фрункціонування сучасної організації. ДВНЗ «Київ. нац. екон. ун-т ім. В. Гетьмана». Київ : КНЕУ, 2019. С. 59-61.

2. Денисенко М.П., Будякова О.Ю. Кадрова політика як основа формування інноваційної стратегії управління персоналом підприємства. Вчені записки Університету "КРОК" (економічні науки). 2018. № 4(52). С. 231-238.

3. Сівальнева М.М., Швеков А.В. Управління персоналом як елемент системи конкурентних переваг організації. Управління персоналом. 2015. № 22. С.17-21.
4. Касич А.О. Методичні підходи щодо оцінки ефективності діяльності підприємства. Бізнес-Інфоорм. 2016. № 12. C. $55-59$.

5. Дорошенко Г.О. Ефективність системи управління підприємством: теоретико-методологічні аспекти та механізми реалізації : монографрія / за заг. ред. Г. О. Дорошенка. Харків : НТМТ, 2014. 424 с.

6. Касич А.О. Методичні підходи щодо оцінки ефективності діяльності підприємства. Бізнес-Інформ. 2012. № 12. С. $55-59$.

7. Хруцький В.Є. Оцінка персоналу. Критика теорії і практики застосування системи збалансованих показників. М. : Фінанси і статистика, 2015. 224 с.

8. Бушуєва І.А. Кадрова політика організації в умовах кризи. Перший крок у науку. 2015. № 9-10. С. 36-40.

9. Виханський О.С. Стратегічне управління: підручник. М. : "Гардарика", 2012. 296 с.

10. Кононова І. В. Класифрікація стратегій розвитку соціальноекономічних систем. Науковий вісник Ужгородського національного університету. 2017. Випуск 14. С. 146-150.

11. Сівальнева М.М., Швеков А.В. Управління персоналом як елемент системи конкурентних переваг організації. Управління персоналом. 2013. № 22. С.17-21.

\section{References:}

1. Vonberg T.V. (2019) HR analituka yak pidgrunttya funkcionyvannya sychasnoy organizatii. Kiev: KNEU, pp. 59-61.

2. Denysenko M.P., Budyakova O.Y. (2018) Kadrova polituka yak osnova formyvannya innovatiynoi strategii ypravlinnya personalom pidpruemstva. Academic notes from KROK University (Economics). no. 4(52), pp. 231-238.

3. Sivalneva M.M., Shvekov A.V. (2015) Upravlinnya personalom yak element sustemu konkyrentnuh perevag organizatii. Personnel management, no. 22, pp. 17-21.

4. Kasich A.A. (2016) Metoduchni pidhodu schodo ocinku efektuvnosti diyalnosti pidpruemstva. Business-Inform, no. 12 , pp. 55-59.

5. Doroshenko G.O. (2014) Efectuvnist sustemu ypravlinnya pidpruemstvom: theoretuko-metodologichni aspektu ta mehanizmu realizatii. Kharkiv: NTMT, 424 p. (in Ukranian) 
6. Kasich A.A. (2012) Metoduchni pidhodu schodo ocinku efektuvnosti diyalnosti pidpruemstva. Business-Inform, no. 12 , pp. 55-59.

7. Khrutsky V.E. (2015) Ocenka personala. Kritika teorii $i$ praktiki primeneniya sistemu cbalansirovannuh pokazateley. Moscow: Finance and Statistics, 224 p. (in Russian)

8. Busheva I.A. (2015) Kadrova polituka organizatii v ymovah kruzu. The first step in science, no. 9-10, pp. 36-40.
9. Vyhansky O.S. (2012) Strategicheskoe ypravlenie: A Textbook. M. : Gardarika, 296 p. (in Russian)

10. Kononova I.V. (2017) Klasufikatiya strategiy rozvutky sotialno-ekonomichnuh sustem. Scientific Bulletin of Uzhgorod National University, no. 14, pp.146-150.

11. Sivalneva M.M., Shvekov A.V. (2013) Ypravlinnya personalom yak element sustemu konkurentnuh perevag organizatii Personnel management, no. 22, pp.17-21. 